\title{
Influence of initial tissue nutrient status of tropical marine algae on response to nitrogen and phosphorus additions
}

\author{
Peggy Fong*, Katharyn E. Boyer, Krista Kamer, Karleen A. Boyle \\ University of California, Los Angeles, Department of Organismic Biology, Ecology, and Evolution, 621 Charles E. Young \\ Drive South, Los Angeles, California 90095-1606, USA
}

\begin{abstract}
We conducted a 3-factor nutrient-enrichment experiment (factors: N, P, initial tissuenutrient status) on common species of macroalgae collected from 2 sites along SW Puerto Rico. Our objective was to determine the relative importance of $\mathrm{N}$ - or P-limitation among species and sites and to investigate the role of tissue-nutrient status in the response to increased nutrient supply. Acanthophora spicifera, Dictyota cervicornis, and Hypnea musciformis initially depleted in tissue nutrients responded strongly to either $+\mathrm{N}$ or $+\mathrm{P}$ alone and both nutrients together by increasing growth. In contrast, growth of these macroalgae with enriched internal stores of nutrients was generally not as nutrient-limited. In our $3 \mathrm{~d}$ experiments, the calcified alga Halimeda incrassata never showed a growth response, perhaps due to the short duration or adaptation to sediment nutrient supply. Tissue $\mathrm{N}$-stores in all algae with low internal nutrient concentrations increased in response to $+\mathrm{N}$, whereas initially higher $\mathrm{N}$-stores were diluted to support growth during the experiment. In addition, all algae depleted the added $\mathrm{N}$ and $\mathrm{P}$ from the water over the course of the experiment, regardless of tissuenutrient status. Depleted algae also took up dissolved organic nitrogen (DON) as a secondary source of $\mathrm{N}$, either directly or after mineralization, whereas enriched algae may have 'leaked' $\mathrm{NH}_{4}$. Our results demonstrated that prior storage of nutrients strongly influenced the response of a number of tropical algal species to increased nutrient supply. This variable response to nutrients within and among algae from 3 major algal divisions over small geographical scales may partially explain the mixed results in previous studies of $\mathrm{N}$ - and P-limitation.
\end{abstract}

KEY WORDS: Tropical macroalgae $\cdot$ Tissue nutrient status $\cdot$ Limitation $\cdot$ Nitrogen $\cdot$ Phosphorus $\cdot$ DON

\section{INTRODUCTION}

The importance of nitrogen- $(\mathrm{N})$ and phosphorus- $(\mathrm{P})$ limitation in controlling growth and biomass accumulation of primary producers has been firmly established in temperate marine systems (e.g. Nixon 1995, Nixon et al. 1995, Taylor et al. 1995, Gallegos \& Jordan 1997, Sfriso \& Marcomini 1997, Lyngby et al. 1999). In contrast, there has been considerable debate over how widespread or important nutrient limitation is for tropical algae (e.g. Szmant 1997, McCook 1999). Some question whether algae in tropical systems are usually, or ever, limited by nutrients. One rationale that has been advanced is that if tropical algal turfs, ubiquitous on reefs worldwide, are extremely productive even in areas characterized by low water column nutrients (Hatcher 1988, McCook 1999), then they cannot be nutrient-limited. To support this, Williams \& Carpenter (1998) provided evidence that supply of solutes to algal turfs may be more limited by boundary layers than concentration. A second rationale has focused on field studies where water nutrient concentrations do not correlate with algal growth or abundance in the field. For example, differences in nutrients across the Australian Great Barrier Reef (GBR) did not lead to differences in growth of Sargassum spp. (McCook 1996, 1999); it was concluded that nutrients were always sufficient for growth, even offshore, where anthropogenic inputs were presumably low. 
Experimental studies of nutrient limitation of tropical algae have had mixed results. In a large-scale field experiment in Australia, turf algae were thought to be nutrient-replete when no measurable increases in photosynthesis or growth rate were found with longterm nutrient additions (Larkum \& Koop 1997, Koop et al. 2001). Populations of Caulerpa taxifolia, a seaweed that successfully invaded and proliferated in the Mediterranean, were nutrient-sufficient and did not respond to nutrient enrichment during most seasons (Delgado et al. 1996). In contrast, nutrients stimulated growth of Sargassum spp. from the GBR (Schaffelke \& Klumpp 1997, 1998a,b) as well as Dictyota divaricata, Gracilaria tikvahiae, and Acanthophora spicifera from Caribbean and Florida reefs (Lapointe 1987, 1989, Lapointe et al. 1987). Mixed results were documented for different algal species within one study; Lapointe (1997) found photosynthesis of 2 dominant species of macroalgae (Chaetomorpha linum and Codium isthmocladum) in Jamaica and Florida was nutrient-limited, whereas 3 other species (Halimeda opuntia, Lobophora variegata, and Sargassum polyceratium) did not respond to increased nutrients. Because of these conflicting results, the importance of nutrient limitation for tropical algae is still controversial.

One possible explanation for the mixed results of nutrient-limitation experiments for macroalgae may be differences in initial tissue-nutrient status of algae that were not taken into consideration during experimental design. Tissue-nutrient status in algae is a function of nutrient history; algae subject to excessive or pulses of nutrients may store nutrients for future growth (Wheeler \& North 1980, Lapointe \& Duke 1984, Fong et al. 1994). Several investigators (e.g. Fujita 1985, McGlathery et al. 1996) found that tissue-nutrient status affected $\mathrm{N}$-uptake rates of algae; algae with nutrient-enriched tissues always took up $\mathrm{N}$ more slowly than nutrient-depleted algae. Hanisak (1983) determined that internal nutrient concentration was positively associated with growth of macroalgae. These studies suggest that algae with higher internal nutrient content are less likely to be limited by external concentration of that nutrient.

Quantifying the relative roles of $\mathrm{N}$ - and P-limitation has become an important focus of tropical marine research in recent years. In contrast to temperate systems (Fujita et al. 1989, Thybo-Christesen et al. 1993, Rivers \& Peckol 1995, Taylor et al. 1995, Gallegos et al. 1997, Sfriso \& Marcomini 1997), several studies found $\mathrm{P}$ to limit productivity and growth more frequently than $\mathrm{N}$ in tropical systems (Lapointe 1987, 1989, Lapointe et al. 1992). However, these studies did find $\mathrm{N}$ to be important, at least seasonally. Others found stimulation by both N and P in summer for Sargassum baccularia from the GBR (Schaffelke \& Klumpp 1998a) and in winter for Gracilaria tikvahiae in the Florida Keys (Lapointe 1987). There are several possible explanations why there is high spatial and temporal variability in the relative importance of $\mathrm{N}$ - and P-limitation in tropical systems. The strength of P-limitation has been related to the amount of P-adsorbing carbonate in sediments (Lapointe et al. 1992, Delgado \& Lapointe 1994, McGlathery et al. 1994) and the habitat or substrate type the alga occupied (Littler et al. 1988, Lapointe 1989). Others hypothesized that the relative importance of $\mathrm{N}$ - and P-limitation varies across a nutrient supply gradient, with $\mathrm{N}$ increasing in importance in more eutrophic systems (Delgado \& Lapointe 1994, Downing et al. 1999). Two studies from Kaneohe Bay, Hawaii, an area with a history of nutrient enrichment, supported this hypothesis as they found $\mathrm{N}$ to be limiting to 9 of 10 species tested from across a broad range of functional forms of algae (Larned \& Stimson 1997, Larned 1998).

Two indirect approaches have been used extensively to determine whether $\mathrm{N}$ and/or $\mathrm{P}$ limits productivity of marine macroalgae. In the first approach, N:P ratios of dissolved inorganic nutrients in the water column have been used as a measure of nutrient availability; water column N:P ratios are compared to nutrient requirements of algae to determine limitation (e.g. Redfield et al. 1963, Lapointe 1989, Duarte 1992, Wheeler \& Björnsäter 1992). However, different species or functional forms of algae may require nutrients in differing proportions; one study found that one alga was limited by $\mathrm{N}$ and another by $\mathrm{P}$ when grown together in seawater of the same N:P ratio (Fong et al. 1994). In addition, water column measures provide only a snapshot in time and may not adequately characterize availability in many tropical areas where nutrients are supplied in pulses (McCook 1999). In the second approach, N:P ratios in algal tissue have been used to predict nutrient limitation (Lapointe et al. 1992, Wheeler \& Björnsäter 1992). However, this method also has limitations, because differing uptake and storage capacities of algae may confound the relationship. For example, if both $\mathrm{N}$ and $\mathrm{P}$ are abundant in the water, and an alga has a greater uptake ability and storage capacity for $\mathrm{N}$ than $\mathrm{P}$, then the resultant high tissue $\mathrm{N}$ :P ratio would indicate P-limitation when limitation by nutrients was not occurring. Sfriso (1995) suggested that either $\mathrm{N}$ or $\mathrm{P}$ could be considered limiting to a single algal species in the lagoon of Venice, depending on what measure of limitation was used (tissue $\mathrm{N}$ content vs water column nutrients).

A third approach that has been used to determine $\mathrm{N}$ - or P-limitation is factorial enrichment experiments adding $\mathrm{N}$ and $\mathrm{P}$ alone and in combination, and quantifying response variables such as photosynthesis, growth, and changes in tissue and water column 
N- and P-content (e.g. Lapointe 1987, 1989, Fong et al. 1993, Larned 1998). When addition of a nutrient increased photosynthesis or growth, it was considered to be limiting. The advantage of this experimental approach was that it provided direct rather than indirect evidence of limitation. In this study, we conducted a factorial nutrient enrichment experiment: (1) to test whether nutrients limited algal growth and tissue Nand P-content of several tropical algal species; (2) to determine the relative importance of $\mathrm{N}$ - or P-limitation; and (3) to investigate the role of algal tissuenutrient status on response of algae to enrichment.

\section{MATERIALS AND METHODS}

We tested the effect of $\mathrm{N}$ and $\mathrm{P}$ addition $(+\mathrm{N},+\mathrm{P})$ on several species of macroalgae from 2 sites on the SW coast of Puerto Rico. Earlier work showed that algae from these sites had very different tissue-nutrient status, and limited sediment and water sampling suggest these sites were subject to different patterns of nutrient supply (Fong et al. 2001). One site that was characterized by algae with enriched tissues was adjacent to sewage leach ponds for secondarily treated wastewater (Site 1: Fong et al. 2001). This site also had relatively enriched sediments for a tropical habitat with mean total $\mathrm{N}$ of $0.24 \%$ dry wt $(\mathrm{SE}=0.02)$, total $\mathrm{P}$ of $0.035 \%$ dry wt $(\mathrm{SE}=0.004)$, and extractable $\mathrm{P}$ (Olsen-P) of $48.48 \mathrm{ppm}$ ( $\mathrm{SE}=5.20$ ). One time sampling by Fong et al. (2001) also found the water column to be relatively enriched, with dissolved organic nitrogen (DON) of $54.76 \mu \mathrm{M}(\mathrm{SE}=2.38)$ and dissolved inorganic nitrogen (DIN) of $15.00 \mu \mathrm{M}(\mathrm{SE}=5.77)$. Longer-term studies found inorganic nutrients in the water column varied widely (J. Corredor, D. B. Ballantine pers. comm.), suggesting that nutrients may be supplied in pulses at this site. The second site was over $10 \mathrm{~km}$ upcurrent from the sewage ponds (Site 2). Fong et al. (2001) characterized the algae from this site as low or depleted in nutrients. They also found that sediment nutrients were far lower with sediment total $\mathrm{N}$ of $0.06 \%$ dry wt $(\mathrm{SE}=0.00)$, sediment total $\mathrm{P}$ below the detection limit in all samples $(<0.010 \% \mathrm{P})$, and Olsen$\mathrm{P}$ of $27.94 \mathrm{ppm}$ ( $\mathrm{SE}=12.52)$. One time sampling found the water column to be less nutrient-enriched than Site 1; water column DON was $42.86 \mu \mathrm{M}$ (SE = 18.90) and DIN was $3.93 \mu \mathrm{M}(\mathrm{SE}=0.36)$ (Fong et al. 2001).

We conducted a 3-factor experiment (factors: N, P, initial tissue-nutrient status) for each of 3 species of macroalgae. $\mathrm{N}$ and $\mathrm{P}$ were added in a $2 \times 2$ factorial design: no nutrient addition control $(\mathrm{C}), \mathrm{N}$-enriched $(+\mathrm{N}), \mathrm{P}$ - enriched $(+\mathrm{P})$, and $\mathrm{N}$ - and P-enriched $(+\mathrm{N}+\mathrm{P})$. There were 2 levels of initial algal tissue-nutrient status, enriched and depleted, corresponding to algae collected from Sites 1 and 2 described above. Replication of experimental units was 5-fold for each treatment. Each replicate experimental unit consisted of a given mass (see below) of 1 species of algae in the appropriate treatment solution.

Three species of algae from each site were used in this experiment: Acanthophora spicifera, Dictyota cervicornis, and Halimeda incrassata. We also used Hypnea musciformis from the depleted tissue-nutrient site, but not the enriched, as it was not in sufficient abundance at that site. Thus, the $H$. musciformis portion of the experiment was a 2-factorial experiment (factors: $N$, P). These algae were common members of the benthic shallow-water community, represented 3 major divisions of marine macroalgae (Rhodophyta, Phaeophyta, and Chlorophyta), and 3 of 4 have been documented to form nuisance blooms in tropical systems. A. spicifera and $H$. musciformis are coarsely branched pseudoparenchymatous, corticated algae in the Division Rhodophyta. H. musciformis formed nuisance blooms in Hawaiian reefs (P. F. unpubl. data). A. spicifera is widespread, occasionally forming dense mats on reefs and seagrass beds in Puerto Rico (P. F. pers. obs.). D. cervicornis is a dichotomously branched brown alga with a sheet-like morphology (sensu Litter \& Litter 1980) 3 cell layers thick that often forms dense mats on coral reefs (Lirman \& Biber 2000). All 3 of these algal species have relatively high surface area-to-volume ratios. In contrast, $H$. incrassata is a rhizophytic alga in Division Chlorophyta; the thallus is composed of a single cell arranged into thick, heavily calcified segments and a bulbous holdfast that allows access to sediment nutrients. This alga has a relatively low surface area-to-volume ratio and, to our knowledge, is not associated with nuisance algal blooms. Hanisak et al. (1988) found that differences in surface area-to-volume ratios, even within a species, were important in explaining differences in net photosynthesis and growth.

Seawater and algae from each site were collected immediately prior to the initiation of the experiments on January 16, 1998. Control seawater was ambient water from each site at the time of collection, whereas nutrient addition treatments were made by adding $\mathrm{NO}_{3}$ and $\mathrm{PO}_{4}$ to batches of ambient seawater to achieve enrichment levels of approximately $20 \mu \mathrm{M} \mathrm{N}$ and $2 \mu \mathrm{M}$ P above ambient (see Table 1). $\mathrm{NO}_{3}$ was used as the added source of inorganic $\mathrm{N}$ as water column sampling suggested that $\mathrm{NH}_{4}$ is usually in low concentration. We did not compare initial concentrations of inorganic $\mathrm{N}$ or total $\mathrm{P}$ (TP) with 3-factor ANOVA as many of the unenriched treatments had values below detection limits. However, we did conduct a $t$-test comparing initial concentrations of $\mathrm{NO}_{3}$ in water from both sites in all treatments where $\mathrm{N}$ was added (pooling $+\mathrm{N}$ and $+\mathrm{N}+\mathrm{P}$ treatments) versus all treatments without 
Table 1. Initial nutrient levels $(\mu \mathrm{M})$ in experiments. Initial solutions were prepared by adding nutrients to ambient seawater (Control) taken from each site. Numbers in parentheses are SEs of the mean. TP: total P; DON: dissolved organic N. For initial concentrations, $\mathrm{n}=3$ except where the number in parentheses indicates $\mathrm{n}$ rather than SE. When $\mathrm{n}<3$, the other replicates were below detection limits (BDL). When $\mathrm{n}=2$, the average of the 2 values is given; when $\mathrm{n}=1$, the single value is reported. Detection limit for all forms of $\mathrm{N}=3.57 \mu \mathrm{M}$, for $\mathrm{p}=1.61 \mu \mathrm{M}$

\begin{tabular}{|c|c|c|c|c|}
\hline & Control & $+\mathrm{P}$ & $+\mathrm{N}$ & $+\mathrm{N}+\mathrm{P}$ \\
\hline \multicolumn{5}{|c|}{ Site 1: Enriched algae } \\
\hline $\mathrm{NO}_{3}$ & $3.93(\mathrm{n}=2)$ & $4.29(\mathrm{n}=2)$ & $24.52(0.24)$ & $25.48(0.63)$ \\
\hline TP & $1.88(\mathrm{n}=2)$ & $4.06(0.65)$ & 1.61 (n =1) & $3.96(0.09)$ \\
\hline DON & $84.29(28.37)$ & $20.00(4.65)$ & $35.72(17.98)$ & $36.90(11.36)$ \\
\hline $\mathrm{NH}_{4}$ & $4.29(\mathrm{n}=1)$ & $6.19(0.24)$ & BDL & $3.57(\mathrm{n}=1)$ \\
\hline \multicolumn{5}{|c|}{ Site 2: Depleted algae } \\
\hline $\mathrm{NO}_{3}$ & $4.29(0.41)$ & $3.93(\mathrm{n}=2)$ & $16.62(1.99)$ & $17.00(1.76)$ \\
\hline $\mathrm{TP}$ & $1.72(\mathrm{n}=2)$ & $3.54(0.10)$ & $1.72(\mathrm{n}=2)$ & $3.75(0.18)$ \\
\hline DON & $50.00(25.08)$ & $26.19(4.76)$ & $42.86(10.91)$ & $35.71(14.29)$ \\
\hline $\mathrm{NH}_{4}$ & BDL & BDL & BDL & BDL \\
\hline
\end{tabular}

$+\mathrm{N}$ (pooling $\mathrm{C}$ and $+\mathrm{P}$ treatments). Similarly, we conducted another $t$-test comparing total $\mathrm{P}$ in the water for treatments with and without added $\mathrm{P} . \mathrm{NO}_{3}$ concentration in the water where $\mathrm{NO}_{3}$ was added was significantly greater than in unenriched treatments ( $\mathrm{p}<$ 0.0001), and total $\mathrm{P}$ was greater in P-enriched treatments $(p<0.0001)$. Thus, our nutrient additions were effective in enriching the water. $\mathrm{NH}_{4}$ was unaffected by nutrient enrichment; $\mathrm{NH}_{4}$ was below detection limits in all of the samples from Site 2 and in 7 of 12 of the samples from Site 1 (Table 1). A 3-factor ANOVA (factors: $+\mathrm{N}$, $+\mathrm{P}$, Site) was used to detect any initial differences in DON among treatments. Initial concentrations of DON ranged widely (20 to $85 \mu \mathrm{M})$, but did not vary significantly among treatments.

Macroalgae from both sites were collected on the same day and sorted and rinsed in seawater from the appropriate site to remove sediments and invertebrates. As in Fong et al. (2001), both Acanthophora spicifera and Dictyota cervicornis had significantly higher initial tissue $\mathrm{N}$ - and P-content (Table 2) in samples collected from Site 1 ( $\mathrm{n}=5$ for all $t$-tests: $\mathrm{p}=0.0006$ for $\mathrm{N}$ and 0.0002 for $\mathrm{P}$ in $D$. cervicornis; $\mathrm{p}=0.0001$ for $\mathrm{N}$ and 0.0034 for $\mathrm{P}$ in $A$. spicifera). In contrast to the other species, tissue $\mathrm{N}$ - and P-content of Halimeda incrassata was lower in algal tissue collected from Site 1 than Site 2 ( $\mathrm{n}=5$ for both $t$-tests: $\mathrm{p}=0.0001$ for $\mathrm{N}_{\mathrm{i}} 0.040$ for P). It was expected that $H$. incrassata would have the lowest $\mathrm{N}$ - and P-content (as \% dry wt) because it is heavily calcified with a large \% of dry wt as $\mathrm{CaCO}_{3}$. It is also a rhizophytic alga; for this experiment, we only used the aboveground, nonrhizoidal portions of the algal thallus. It is possible that, as a rhizophytic alga, $H$. incrassata had access to sources of nutrients not available to other algae, and therefore did not store nutrients in proportion to nutrient history of the collection site. Another possibility is that $H$. incrassata was more heavily calcified at Site 1 compared to Site 2, reducing the \% dry wt of nutrients, while not necessarily changing the amount of nutrients available for growth. However, we did not quantify calcification. Hypnea musciformis was abundant enough to collect only at Site 2 .

Experimental units were plastic jars containing $300 \mathrm{ml}$ of treatment seawater and $2 \mathrm{~g}$ wet wt of algae. To measure biomass, algal thalli were placed in mesh bags, spun for $1 \mathrm{~min}$ in a salad spinner to remove excess water, and weighed. The $2 \mathrm{~g}$ algal mass used in each experimental unit was taken from a single algal thallus trimmed to the correct size. Care was taken to include several apical growing tips in each unit. Each algal sample was placed into the appropriate seawater solution, and the jars were placed in a random array in an outdoor flowthrough water table to maintain ambient temperature. Because experimental units were static and not flowthrough, this experiment should be considered a 'bioassay', or a simple attempt to determine whether $\mathrm{N}$ or $\mathrm{P}$ is limiting, rather than an attempt to model the response of algae in the field. Thus, growth rates and algal tissue $\mathrm{N}$ - and $\mathrm{P}$-contents can be compared within the experiment, but should not be extrapolated to natural systems. Jars were screened to reduce ambient light by approximately $30 \%$. The experiment lasted $3 \mathrm{~d}$.

Table 2. Mean initial tissue nutrients as \% dry wt and as total $\mathrm{N}$ mass in algal tissue per experimental unit. Numbers in parentheses are SE of the mean, $n=5$

\begin{tabular}{|lcccc|}
\hline & $\begin{array}{c}\text { Tissue N } \\
(\% \text { dry wt) }\end{array}$ & $\begin{array}{c}\text { Tissue P } \\
(\% \text { dry wt) }\end{array}$ & $\begin{array}{c}\text { Mass N } \\
\text { (total mg in } \\
\text { tissue) }\end{array}$ & $\begin{array}{c}\text { Mass P } \\
\text { (total mg in } \\
\text { tissue) }\end{array}$ \\
\hline Site 1: Enriched algae & & & & \\
Acanthophora spicifera & $2.134(0.108)$ & $0.088(0.012)$ & $4.27(0.22)$ & $0.18(0.03)$ \\
Dictyota cervicornis & $1.480(0.065)$ & $0.066(0.004)$ & $2.85(0.08)$ & $0.13(0.01)$ \\
Halimeda incrassata & $0.619(0.022)$ & $0.024(0.002)$ & $1.24(0.04)$ & $0.05(0.01)$ \\
Site 2: Depleted algae & & & & \\
Acanthophora spicifera & $1.048(0.038)$ & $0.040(0.003)$ & $2.10(0.08)$ & $0.07(0.01)$ \\
Dictyota cervicornis & $1.119(0.040)$ & $0.040(0.000)$ & $2.24(0.08)$ & $0.08(0.00)$ \\
Halimeda incrassata & $1.011(0.028)$ & $0.030(0.000)$ & $2.02(0.06)$ & $0.06(0.00)$ \\
Hypnea musciformis & $0.93(0.07)$ & $0.050(0.014)$ & $1.90(0.03)$ & $0.09(0.00)$ \\
\hline
\end{tabular}


Algal biomass and tissue nutrients were measured at the conclusion of the experiment. Biomass (wet wt) was determined as above and percentage change in biomass calculated. Algal samples were then briefly rinsed in distilled water to remove salts and dried at $60^{\circ} \mathrm{C}$ to a constant weight. Samples were ground with a mortar and pestle and analyzed for tissue $\mathrm{N}$ - and $\mathrm{P}$ content (\% dry wt) at the Division of Agriculture and Natural Resources (DANR) Analytical Laboratory at the University of California, Davis, using standard methods. The method for total $\mathrm{N}$ quantitatively determines the amount of $\mathrm{N}$ in all forms $\left(\mathrm{NH}_{4}, \mathrm{NO}_{3}\right.$, protein and heterocyclic $\mathrm{N}$ bound in a carbon ring) using an induction furnace and a thermal conductivity detector (Sweeney 1989). The method for total P quantitatively determines the concentration of $\mathrm{P}$ utilizing a nitric acid/hydrogen peroxide microwave digestion (Johnson \& Ulrich 1959) and inductively coupled plasma atomic emission spectrometry (ICP-AES; Franson 1985). In general, all algae, except for Halimeda incrassata, dried to about $10 \%$ of wet wt. Thus, there was very little dried tissue. When amount of dried tissue was limiting, we chose a priori to prioritize measures of tissue N. Algal biomass in each independent experimental unit was insufficient to allow analysis of tissue $\mathrm{P}$ for any species except for $H$. incrassata.

We reported tissue nutrients as a \% change from initial concentration: $100 \times$ (final \% dry wt - initial \% dry wt) / initial \% dry wt. We also calculated the total $\mathrm{N}$ or $\mathrm{P}$ mass contained within all algal tissue in each experimental unit at the end of the experiment (\% dry wt $\mathrm{N}$ or $\mathrm{P} / 100 \times \mathrm{mg}$ total dry wt of algae). We use both measures of tissue nutrients in order to be able to compare $\mathrm{N}$-content of algae with different amounts of growth over the course of the experiment. Growth dilutes concentration, therefore assessing total mass in the tissue is a measure of accumulation.

Water from each experimental unit was filtered through a Whatman GF/C glass fiber filter, frozen immediately, then analyzed for $\mathrm{DON}, \mathrm{NH}_{4}, \mathrm{NO}_{3}$, and TP by DANR. DON was measured by quantifying dissolved total Kjeldahl $\mathrm{N}$ (TKN) and subtracting $\mathrm{NH}_{4}$ concentration. The TKN method is based on the wet oxidation of $\mathrm{N}$ using sulfuric acid and a digestion catalyst. The procedure does not digest $\mathrm{N}$ from oxidized forms such as $\mathrm{NO}_{3}$ and $\mathrm{NO}_{2} . \mathrm{NH}_{4}$ and $\mathrm{NO}_{3}$ are measured by the diffusion-conductivity method as described by Carlson (1978). TP in seawater is measured following methods for algal material (above). These automated methods have detection limits of $3.57 \mu \mathrm{M}$ for all forms of $\mathrm{N}$ and $1.61 \mu \mathrm{M}$ for P. These are relatively high for tropical water samples. However, the expense of methods using lower detection limits prohibited their use for this project. Thus, much of the water nutrient data was below detection limits.
All data were tested for normality and homogeneity of variance to ensure that they conformed to assumptions of ANOVA; no transformations were necessary. Algal biomass, tissue-nutrient concentration as \% dry wt, and $\mathrm{N}$ and $\mathrm{P}$ mass in algal tissue were analyzed using 3-factor ANOVA (factors: $+\mathrm{N},+\mathrm{P}$, initial tissuenutrient status) for Acanthophora spicifera, Dictyota cervicornis, and Halimeda incrassata. A 2-factor ANOVA (factors: $+\mathrm{N},+\mathrm{P}$ ) was conducted on all response variables for Hypnea musciformis. Due to low sample sizes associated with detection limits, initial and final water samples with measurable concentrations of DON, $\mathrm{NH}_{4}, \mathrm{NO}_{3}$, and TP were compared with $t$-tests to determine changes during the course of the experiment. Separate comparisons were made for water $\mathrm{NO}_{3}$ and TP in enriched and unenriched treatments due to the large differences among initial means. Therefore, for $\mathrm{NO}_{3}$, we ran one $t$-test comparing final versus initial concentrations for pooled $+\mathrm{N}$ and $+\mathrm{N}+\mathrm{P}$ treatments, and in another we compared control and $+\mathrm{P}$. Similarly, for $\mathrm{TP}$, we compared initial versus final for enriched $(+\mathrm{P}$, $+\mathrm{N}+\mathrm{P})$ treatments in a separate $t$-test from unenriched $($ control, $+\mathrm{N})$ treatments.

\section{RESULTS}

\section{Acanthophora spicifera}

There were significant effects of $+\mathrm{N}$ and $+\mathrm{P}$ as well as initial tissue-nutrient status on the growth of Acanthophora spicifera (Fig. 1a,b). Growth was higher for algae from Site 2 compared to Site 1. Overall, growth of algae from both sites increased with addition of either $\mathrm{N}$ or $\mathrm{P}$, resulting in no significant interactions among the factors. However, nutrient effects were not equal for algae from the 2 sites. For algae from Site 2, with tissues initially nutrient-depleted, addition of either $\mathrm{N}$ or $\mathrm{P}$ resulted in an increase in growth of 70 to $90 \%$ over control growth rates. A. spicifera from Site 1, with tissues initially nutrient-enriched, did not have the same magnitude of response to nutrient addition; whereas growth was doubled when $\mathrm{P}$ was added alone, increase in growth with $+\mathrm{N}$-alone was only $30 \%$ over controls. For algae from both sites, the greatest growth rates occurred when both nutrients were added together; growth was 2 to 3 times higher than in controls when both nutrients were added together.

There was an interactive effect of $+\mathrm{N}$ and tissuenutrient status (Fig. 1c,d) on \% change in tissue $\mathrm{N}$ concentration of Acanthophora spicifera. This interaction can be attributed to the differential effects of adding $\mathrm{N}$ to algae with different initial tissue-nutrient status (Table 2). Tissue $\mathrm{N}$ was greater than $2 \%$ dry wt initially, and decreased in all treatments from Site 1 
regardless of nutrient addition due, at least partially, to growth diluting the $\mathrm{N}$ stored in the tissue. Patterns were very different in A. spicifera from Site 2. Initial tissue $\mathrm{N}$ was just over $1 \%$ of the dry wt (Table 2), and increased in all treatments except for the control, resulting in interaction. There was also a significant interaction between $+\mathrm{N}$ and $+\mathrm{P}$ (Fig. 1c,d). Addition of $\mathrm{N}$ alone $(+\mathrm{N})$ algae from Site 2 resulted in more than a $12 \%$ increase in $\mathrm{N}$ in the algal tissue in $3 \mathrm{~d}$. However, when $\mathrm{N}$ and $\mathrm{P}$ were added together, the concentration of $\mathrm{N}$ in the tissue was less than when $\mathrm{N}$ was added alone, causing the significant interaction. This may also be attributed to greater growth in the $+\mathrm{N}+\mathrm{P}$ treatment diluting tissue $\mathrm{N}$ concentration.

There was an interaction between $+\mathrm{P}$ and tissuenutrient status on the $\mathrm{N}$ mass contained in Acanthophora spicifera tissue (Fig. 1e,f). Initial $N$ mass in $A$.

\section{Acanthophora spicifera}

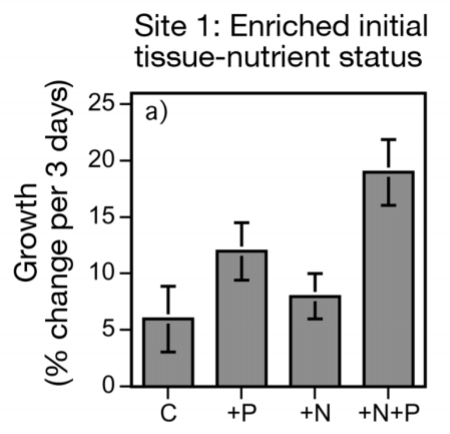

Site 2: Depleted initial tissue-nutrient status

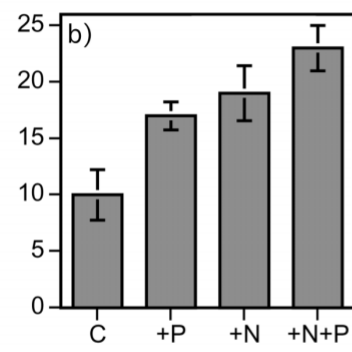

$+\mathrm{N} \quad \mathrm{p}=0.0010$

$+P \quad p=0.0002$

Status $p=0.0010$
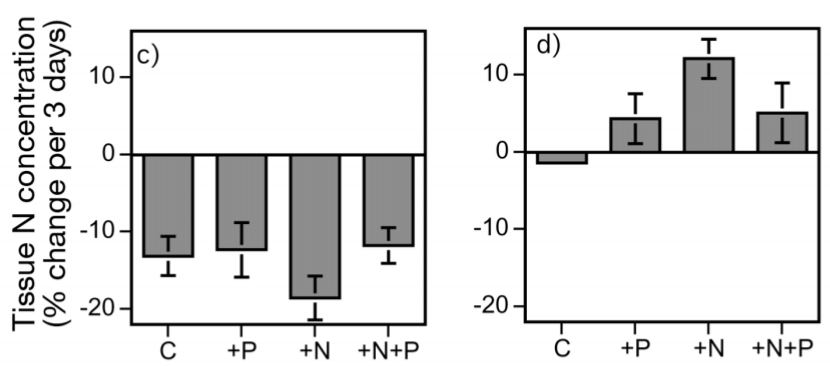

$+\mathrm{N} \quad \mathrm{p}=0.2522$

$+P \quad p=0.4361$

Status $p=0.0001$

$\mathrm{N} \times$ Status $\mathrm{p}=0.02$

$\mathrm{N} \times \mathrm{P} p=0.02$
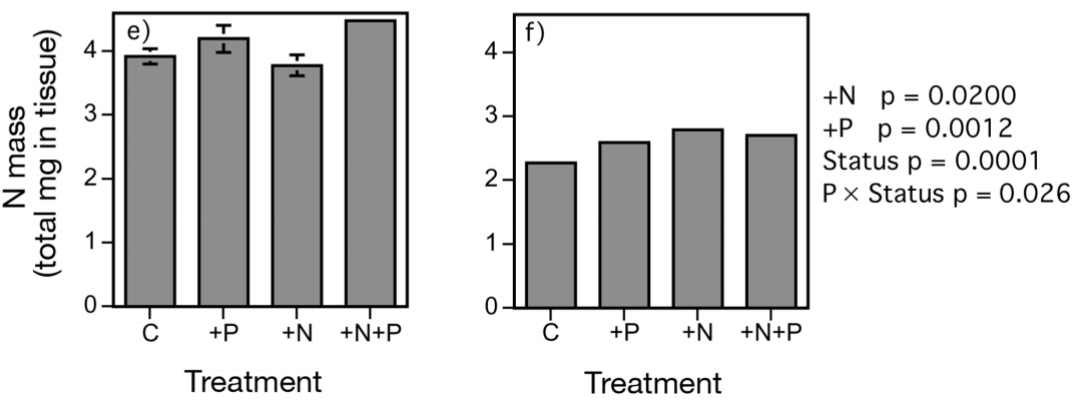

Fig. 1. Acanthophora spicifera. Responses to experimental nutrient addition. Bars $=$ SE. Statistical results of a 3-factor ANOVA are given to the right of each panel. $\mathrm{p}$-values are included for each factor $\left(+\mathrm{N}_{1}+\mathrm{P}\right.$, tissue-nutrient status $)$ as well as for any significant interactions spicifera tissue from Site 1 was $4.27 \mathrm{mg}$ (Table 2), and ned the same or decreased slightly in all exin algal tissue in each experimental unit initially was $2.10 \mathrm{mg}$ (Table 2); over the $3 \mathrm{~d}$ experiment, $\mathrm{N}$ mass in algae increased in all treatments. $\mathrm{N}$ mass was greater an $2.50 \mathrm{mg}$ in all treatments where nutrients were

Over the course of the experiment, $\mathrm{NO}_{3}$ in water was reduced below the detection limit in all but 10 of the imental units with Acanthophora spicifera, treatments ( $t$-test: $\mathrm{p}<0.0001)$, but did not change in units not enriched with $\mathrm{NO}_{3}$ ( $t$-test: $\left.\mathrm{p}=0.6091\right)$. At the end of the experiment, TP was below the detection limit in 15 of 40 experimental units. Final concentration of $\mathrm{TP}$ in $+\mathrm{P}$ treatments with measurable nutrients was lower than initial concentration ( $t$ test: $\mathrm{p}<0.0001)$; TP was reduced to $45 \%$ of initial values. TP was unchanged in treatments not enriched in $\mathrm{P}$ ( $t$-test: $\mathrm{p}=$ $0.3375)$. There was a significant reduction $(58 \%)$ in DON during the experiment ( $t$-test: $\mathrm{p}<0.0001)$, perhaps due to mineralization and/or uptake by algae. At the end of the experiment, $\mathrm{NH}_{4}$ was below the detection limit in 26 of 40 experimental units, or $65 \%$ compared to $70 \%$ initially; there was no difference in mean $\mathrm{NH}_{4}$ concentration between initial and final values of remaining samples ( $t$-test: $\mathrm{p}=0.3779)$.

\section{Dictyota cervicornis}

There were significant effects of $+\mathrm{N}$ and initial tissue-nutrient status on the growth of Dictyota cervicornis, whereas $+\mathrm{P}$ did not have a statistically significant effect at the $\alpha=0.05$ level (Fig. 2a,b). The growth response of algae from Site 2 (initially depleted tissue nutrients) was greater than from Site 1 (initially enriched tissues) across all treatments. While mean growth in control treatments with D. cervicornis from Site 1 was the same as from Site 2, growth in all nutrient addition treatments from Site 1 ranged from 4 to $12 \%$ and was highly variable. In contrast, growth of 
algae from Site 2 increased by $\sim 100 \%$ when $\mathrm{P}$ or $\mathrm{N}$ were added alone, and further increased when both nutrients were added.

Overall patterns of change in $\mathrm{N}$ concentration in the tissue of Dictyota cervicornis were very similar to those of Acanthophora spicifera (Fig. 2c,d). There was an interaction between $+\mathrm{P}$ and initial tissue-nutrient status on the concentration of $\mathrm{N}$ in the tissue of $D$. cervicornis. Tissue $\mathrm{N}$ concentration decreased in all treatments from Site 1, where tissue-nutrient content was initially high (Table 2). Tissue concentrations of $\mathrm{N}$ were reduced up to $20 \%$ from initial values. Patterns in tissue $\mathrm{N}$ concentration of algae from Site 2 were very different. Adding $\mathrm{P}$ reduced the concentration of $\mathrm{N}$ stored in tissue by almost $6 \%$, probably because of the increased growth in this treatment. Mean Ncontent increased by $13 \%$ in the $\mathrm{N}$-alone treatment, but was highly variable. $+\mathrm{N}+\mathrm{P}$ did not result in an increase of tissue $N$, which may be partially attributed to dilution by the large amount of growth in this treatment.

Patterns in total $\mathrm{N}$ mass in the tissue of Dictyota cervicornis were very different from Acanthophora spicifera. There was an effect of $+\mathrm{N}$, but no effect of either tissuenutrient status or $+\mathrm{P}$ on total $\mathrm{N}$ mass (Fig. 2e,f). These differences were due, in part, to the smaller differences among sites in $\mathrm{N}$ mass of $A$. spicifera and $D$. cervicornis initially (Table 2). Initial N mass was $2.85 \mathrm{mg}$ in algae from Site 1 (Table 2), decreasing in all treatments but the $+\mathrm{N}+\mathrm{P}$ during the experiment. In contrast, initial $\mathrm{N}$ mass in $D$. cervicornis tissue was $2.24 \mathrm{mg}$ in algae from Site 2 and increased during the experiment in all treatments. Increases were greatest in the $+\mathrm{N}$ and $+\mathrm{N}+\mathrm{P}$ treatment, resulting in the significant $\mathrm{N}$ effect.

Water column nutrients were also very low after $3 \mathrm{~d}$ with Dictyota cervicornis (Table 3), regardless of nutrient additions. $\mathrm{NO}_{3}$ was below the detection limit in 31 of 40 experimental units. When the remaining final samples for $\mathrm{NO}_{3}$-enriched treatments were pooled and compared to $\mathrm{NO}_{3}$-enriched initial sam- ples, there was significantly less $\mathrm{NO}_{3}$ in final samples (mean $[\mathrm{SE}]=20.91 \mu \mathrm{M}$ [1.37] vs $4.29 \mu \mathrm{M}$ [0.39] for initial vs final; $t$-test: $\mathrm{p}<0.0001)$. There were no differences between initial and final $\mathrm{NO}_{3}$ concentrations for the treatments not enriched in $\mathrm{NO}_{3}$ ( $t$-test: $\mathrm{p}=$ 0.8561). TP was below the detection limit in 11 of 40 units, and in the remaining was lower in final samples compared to initial in P-enriched treatments (mean $[\mathrm{SE}]=2.02 \mu \mathrm{M}[0.19]$ vs $3.58 \mu \mathrm{M}[0.19]$ for final vs initial; $t$-test: $\mathrm{p}<0.0001)$. TP was not different between initial and final concentrations in the unenriched treatments ( $t$-test: $\mathrm{p}=0.2386$ ). Concentrations of DON were

Table 3. Final nutrient levels $(\mu M)$ in experiments. TP: total $P$; DON: dissolved organic $\mathrm{N}$. For final concentrations, $\mathrm{n}=5$; where $\mathrm{n}$ is indicated to be lower, the remainder of the samples were below detection limits (BDL). When $n=2$, the average of the 2 values is given with no estimate of variability; when $\mathrm{n}=1$, the single value is reported. Detection limit for all forms of $\mathrm{N}=3.57 \mu \mathrm{M}$, for $\mathrm{P}=1.61 \mu \mathrm{M}$

\begin{tabular}{|c|c|c|c|c|}
\hline & Control & $+\mathrm{P}$ & $+\mathrm{N}$ & $+\mathrm{N}+\mathrm{P}$ \\
\hline \multicolumn{5}{|c|}{ Acanthophora spicifera } \\
\hline \multicolumn{5}{|c|}{ Site 1: Enriched algae } \\
\hline $\mathrm{NO}_{3}$ & BDL & $4.05(0.48 ; \mathrm{n}=3)$ & $7.86(\mathrm{n}=2)$ & BDL \\
\hline $\mathrm{TP}$ & $2.31(0.35)$ & $2.34(0.45 ; \mathrm{n}=4)$ & $2.00(0.31)$ & $1.88(0.18 ; \mathrm{n}=4)$ \\
\hline DON & $20.57(2.42)$ & $16.57(2.47)$ & $17.98(0.98)$ & $17.00(1.33)$ \\
\hline $\mathrm{NH}_{4}$ & $4.29(\mathrm{n}=1)$ & $12.14(\mathrm{n}=2)$ & $13.39(8.88 ; \mathrm{n}=4)$ & $5.00(1.09 ; \mathrm{n}=3)$ \\
\hline \multicolumn{5}{|c|}{ Site 2: Depleted algae } \\
\hline $\mathrm{NO}_{3}$ & $3.57(\mathrm{n}=1)$ & $\mathrm{BDL}$ & $3.93(\mathrm{n}=2)$ & $3.57(\mathrm{n}=2)$ \\
\hline TP & $1.61(\mathrm{n}=2)$ & $1.61(\mathrm{n}=1)$ & $1.61(\mathrm{n}=2)$ & $1.61(\mathrm{n}=2)$ \\
\hline DON & $17.71(2.77)$ & $23.57(8.57)$ & $12.57(1.77)$ & $17.14(2.86)$ \\
\hline $\mathrm{NH}_{4}$ & $4.29(\mathrm{n}=1)$ & $3.57(\mathrm{n}=1)$ & $4.29(\mathrm{n}=2)$ & BDL \\
\hline \multicolumn{5}{|c|}{ Dictyota cervicornis } \\
\hline \multicolumn{5}{|c|}{ Site 1: Enriched algae } \\
\hline $\mathrm{NO}_{3}$ & $3.57(\mathrm{n}=1)$ & BDL & $3.93(n=2)$ & $3.93(\mathrm{n}=2)$ \\
\hline $\mathrm{TP}$ & $2.27(0.32 ; \mathrm{n}=4)$ & $2.13(0.29)$ & $2.42(0.47 ; \mathrm{n}=4)$ & $2.11(0.37 ; \mathrm{n}=4)$ \\
\hline DON & $11.00(2.03)$ & $13.71(1.40)$ & $20.58(4.38)$ & $13.57(2.06)$ \\
\hline $\mathrm{NH}_{4}$ & $6.14(1.21)$ & $8.57(\mathrm{n}=2)$ & $5.71(\mathrm{n}=2)$ & $9.82(1.53 ; \mathrm{n}=4)$ \\
\hline \multicolumn{5}{|c|}{ Site 2: Depleted algae } \\
\hline $\mathrm{NO}_{3}$ & $4.29(\mathrm{n}=2)$ & $3.57(\mathrm{n}=1)$ & $\mathrm{BDL}$ & $5.71(\mathrm{n}=1)$ \\
\hline $\mathrm{TP}$ & $1.61(\mathrm{n}=1)$ & $1.61(0.00)$ & $1.61(0.00 ; \mathrm{n}=3)$ & $1.61(0.00 ; \mathrm{n}=3)$ \\
\hline DON & $15.72(1.43)$ & $24.14(7.12)$ & $16.43(2.90)$ & $22.86(5.25)$ \\
\hline $\mathrm{NH}_{4}$ & BDL & $3.93(\mathrm{n}=2)$ & $3.57(0.00 ; \mathrm{n}=3)$ & BDL \\
\hline \multicolumn{5}{|c|}{ Halimeda incrassata } \\
\hline \multicolumn{5}{|c|}{ Site 1: Enriched algae } \\
\hline $\mathrm{NO}_{3}$ & $5.00(\mathrm{n}=1)$ & $3.57(\mathrm{n}=1)$ & $\mathrm{BDL}$ & $5.00(\mathrm{n}=1)$ \\
\hline $\mathrm{TP}$ & $1.93(0.15)$ & $2.11(0.37 ; \mathrm{n}=4)$ & $1.94(0.15)$ & $1.81(0.15)$ \\
\hline DON & $13.57(2.60)$ & $16.43(5.09)$ & $15.77(5.49)$ & $32.29(18.75)$ \\
\hline $\mathrm{NH}_{4}$ & $5.95(0.48 ; \mathrm{n}=3)$ & $5.95(1.04 ; \mathrm{n}=3)$ & $7.14(1.62 ; \mathrm{n}=4)$ & $7.86(1.57 ; \mathrm{n}=4)$ \\
\hline \multicolumn{5}{|c|}{ Site 2: Depleted algae } \\
\hline $\mathrm{NO}_{3}$ & $4.29(\mathrm{n}=1)$ & $4.29(\mathrm{n}=2)$ & $3.93(\mathrm{n}=2)$ & $3.57(\mathrm{n}=1)$ \\
\hline $\mathrm{TP}$ & $1.61(0.00 ; \mathrm{n}=3)$ & $1.61(\mathrm{n}=2)$ & $1.61(0.00 ; \mathrm{n}=3)$ & $1.61(0.00 ; \mathrm{n}=4)$ \\
\hline DON & $14.72(2.30)$ & $14.14(2.58)$ & $30.57(10.97)$ & $10.57(2.37)$ \\
\hline $\mathrm{NH}_{4}$ & $5.00(\mathrm{n}=1)$ & $3.93(\mathrm{n}=2)$ & $4.29(\mathrm{n}=1)$ & $4.29(\mathrm{n}=1)$ \\
\hline \multicolumn{5}{|c|}{ Hypnea musciformis } \\
\hline \multicolumn{5}{|c|}{ Site 2: Depleted algae } \\
\hline $\mathrm{NO}_{3}$ & $4.29(\mathrm{n}=2)$ & $3.57(\mathrm{n}=1)$ & $5.00(\mathrm{n}=1)$ & $3.57(\mathrm{n}=1)$ \\
\hline $\mathrm{TP}$ & $1.61(\mathrm{n}=1)$ & $1.61(\mathrm{n}=2)$ & $\mathrm{BDL}$ & $1.61(0.00 ; \mathrm{n}=3)$ \\
\hline DON & $21.63(2.46)$ & $17.86(1.60)$ & $14.86(2.04)$ & $15.00(0.71)$ \\
\hline $\mathrm{NH}_{4}$ & $3.07(\mathrm{n}=2)$ & $3.57(\mathrm{n}=1)$ & $3.81(0.24 ; \mathrm{n}=3)$ & $3.57(\mathrm{n}=1)$ \\
\hline
\end{tabular}




\section{Dictyota cervicornis}

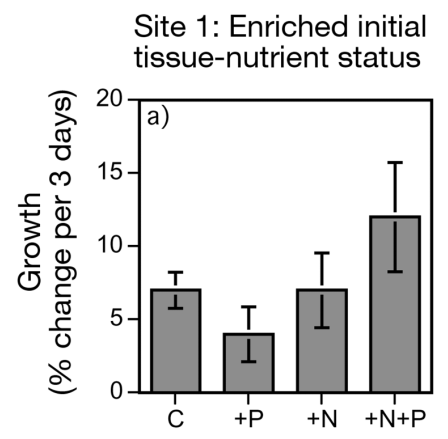

Site 2: Depleted initial tissue-nutrient status
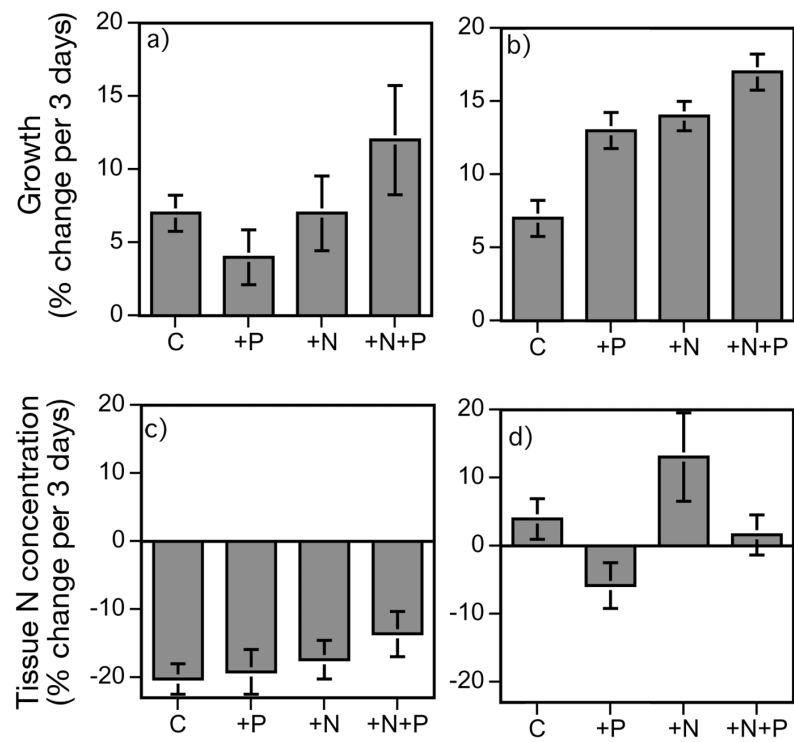

$+\mathrm{N} \quad \mathrm{p}=0.0212$

$+P \quad p=0.1211$

Status $p=0.0001$

$\mathrm{P} \times$ Status $=0.0164$
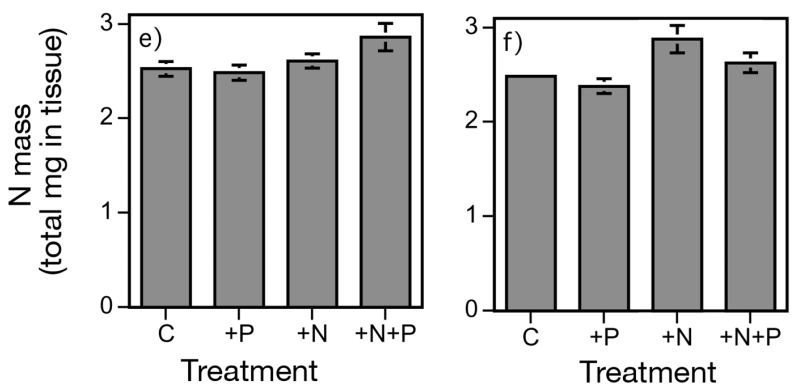

$+\mathrm{N} \quad \mathrm{p}=0.0004$

$+P \quad p=0.6008$

Status $p=0.6809$

Fig. 2. Dictyota cervicornis. Responses to experimental nutrient addition. Bars = SE. Statistical results of a 3-factor ANOVA are given to the right of each panel. p-values are included for each factor $\left(+N_{1}+\mathrm{P}\right.$, tissue-nutrient status $)$ as well as for any significant interactions

reduced from initial values (mean $[\mathrm{SE}]=42.56 \mu \mathrm{M}$ [6.21] vs $17.25 \mu \mathrm{M}$ [1.42] for initial vs final; $t$-test: $\mathrm{p}<$ $0.0001)$. There were no statistical differences between initial and final concentrations of $\mathrm{NH}_{4}$ for pooled data from both sites ( $t$-test: $\mathrm{p}=0.1545)$. However, $\mathrm{NH}_{4}$ was above the detection limit in only $\sim 30 \%$ of initial samples, but more than $50 \%$ of final samples, suggesting some accumulation of $\mathrm{NH}_{4}$ in the water.

\section{Halimeda incrassata}

Mean growth of Halimeda incrassata was low and variable relative to the other species of algae (Fig. 3a,b). There were no significant treatment effects on growth, nor any significant interactions.

There were interactive effects of $+\mathrm{N}$ and $+\mathrm{P}$ as well as $+\mathrm{P}$ and tissue-nutrient status on change in concen- tration of $\mathrm{N}$ in Halimeda incrassata tissue (Fig. 3c,d). These interactions may be attributed to the difference in the response of the $+\mathrm{N}$ and $+\mathrm{N}+\mathrm{P}$ treatments between the different sites. When subject to $+\mathrm{N}$ alone, tissue $\mathrm{N}$ increased in algae from Site 2 (initially higher tissue $\mathrm{N}$ for this species), but decreased in algae from Site 1 (initially lower tissue $\mathrm{N}$ for this species). However, when $\mathrm{N}$ was added with $\mathrm{P}(+\mathrm{N}+\mathrm{P})$, the response was reversed in the algae from Site 1 and $\mathrm{N}$ accumulated in the tissue. Tissue $\mathrm{N}$ concentration increased more in $H$. incrassata from Site 2 than for any other algal species; mean increase in tissue $\mathrm{N}$ ranged from 10.8 to $45.2 \%$. This may be partially due to the lack of growth in this alga. There were significant effects of tissue-nutrient status and $+\mathrm{N}$ on the $\mathrm{N}$ mass in the tissue of $H$. incrassata (Fig. 3e,f). The effect of tissue-nutrient status reflected both differences in initial $\mathrm{N}$ mass (1.24 vs $2.02 \mathrm{mg}$ for Sites 1 vs 2; Table 2) as well as the large increases in $\mathrm{N}$ concentration in the algae from Site 2 (Fig. 3c,d). The effect of $+\mathrm{N}$ on $\mathrm{N}$ mass was due to the increase in $\mathrm{N}$ mass in $+\mathrm{N}$-treatments compared to controls from Site 2.

In general, there was a large range in mean \% change in tissue $\mathrm{P}$ concentration in Halimeda incrassata $(-20.0$ to $73.3 \%)$. There was an interaction between $+\mathrm{N}$ and $+\mathrm{P}$ as well as among all 3 factors on tissue $\mathrm{P}$ concentration of $H$. incrassata (Fig. 3g,h). Three-way interaction demonstrates that the effects of both nutrients varied between sites. $+\mathrm{N}$ alone resulted in an increase compared to controls in tissue $\mathrm{P}$ concentration in algae from Site 2, but a decrease in algae from Site 1. + P alone decreased tissue $\mathrm{P}$ compared to controls from Site 2, but had no effect on algae from Site 1. When N and $\mathrm{P}$ were added together, the $\mathrm{N}$ effect was reversed in algae from Site 1, but not Site 2, contributing to the significant $\mathrm{N} \times \mathrm{P}$ interaction.

There was a significant interaction between $+\mathrm{N}$ and tissue-nutrient status on the $\mathrm{P}$ mass in tissue of Halimeda incrassata (Fig. 3i,j). This may be attributed to the increase in P mass compared to controls in the $+\mathrm{N}$ treatment from Site 2 and the decrease in P mass in the same treatment from Site 1. In general, P mass was greater in the algae from Site 2, reflecting differences in initial mass (0.06 vs $0.05 \mathrm{mg}$; Table 2) and overall greater increases in concentration. 


\section{Halimeda incrassata}

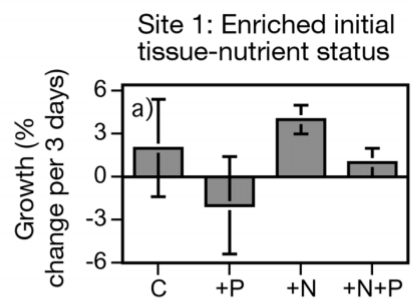

Site 2: Depleted initial tissue-nutrient status
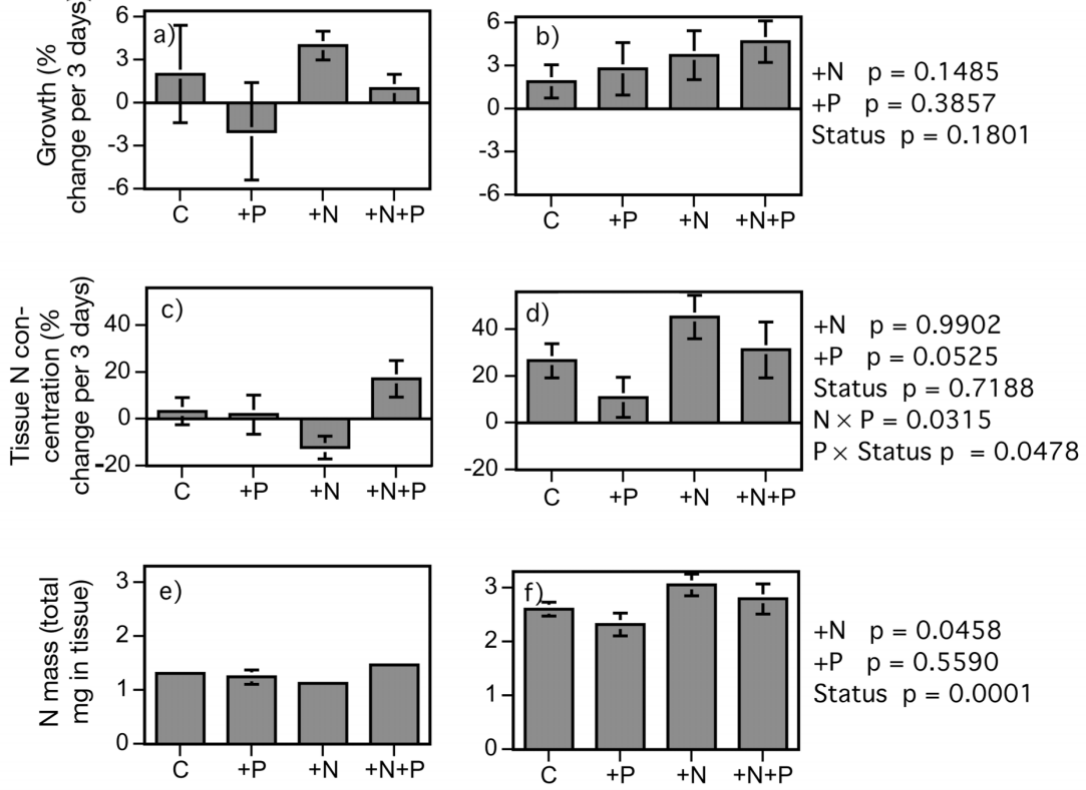

$+\mathrm{N} \quad \mathrm{p}=0.0458$

$+\mathrm{P} \quad \mathrm{p}=0.5590$

Status $p=0.0001$
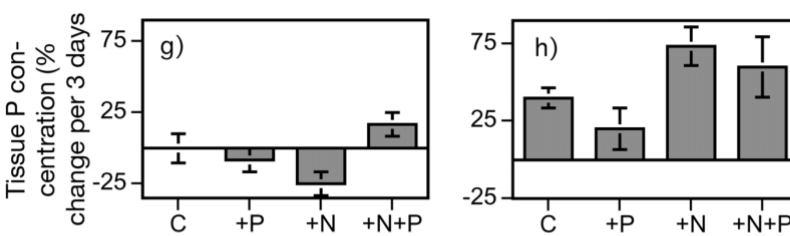

$+\mathrm{N} \quad \mathrm{p}=0.9990$

$+P \quad p=0.0685$

Status $p=0.3478$

$\mathrm{N} \times \mathrm{Pp}=0.0080$

3-way $p=0.0080$
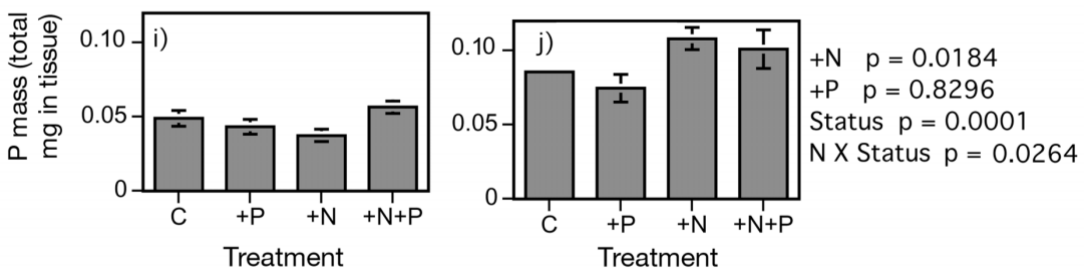

Fig. 3. Halimeda incrassata. Responses to experimental nutrient addition. Bars $=$ SE. Statistical results of a 3 -factor ANOVA are given to the right of each

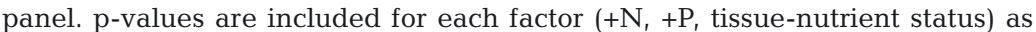
well as for any significant interactions

As for all the other species, Halimeda incrassata reduced the concentration of $\mathrm{NO}_{3}$ and $\mathrm{PO}_{4}$ added to experimental units after $3 \mathrm{~d}$ (Table 3 ). $\mathrm{NO}_{3}$ was below the detection limit in 31 of 40 experimental units at the end of the experiment. Of the remainder, in $\mathrm{N}$ enriched treatments (pooled $+\mathrm{N},+\mathrm{N}+\mathrm{P}$ ), $\mathrm{NO}_{3}$ was reduced from a grand mean of $20.91 \mu \mathrm{M}(\mathrm{SE}=1.37)$ in initial samples to a grand mean of $4.11 \mu \mathrm{M}(\mathrm{SE}=0.35)$ in final samples ( $t$-test: $\mathrm{p}<0.0001) . \mathrm{NO}_{3}$ concentration was unchanged in treatments where $\mathrm{NO}_{3}$ was not added ( $t$-test: $\mathrm{p}=0.8561$ ). TP was below the detection limit in 9 of 40 experimental units at the end of the experiment. In P-enriched treatments (pooled $+\mathrm{P},+\mathrm{N}+\mathrm{P}$ ) above the detection limit TP was reduced from a grand mean of $3.58 \mu \mathrm{M} \quad(\mathrm{SE}=0.19)$ initially to $1.73 \mu \mathrm{M}(\mathrm{SE}=0.70)$ finally ( $t$-test: $\mathrm{p}<$ 0.0001 ) and remained the same in unenriched treatments ( $t$-test: $\mathrm{p}=0.5685$ ). DON was also significantly lower in all final (18.51 $\mu \mathrm{M}, \mathrm{SE}=2.93)$ samples as compared to all initial $(42.56 \mu \mathrm{M}, \mathrm{SE}=$ 6.21) samples ( $t$-test: $\mathrm{p}=0.0002$ ). $\mathrm{NH}_{4}$ was below the detection limit in 21 of 40 units, and in the remainder there was no difference in mean $\mathrm{NH}_{4}$ in final versus initial samples ( $t$-test, $\mathrm{p}=0.3811$ ).

\section{Hypnea musciformis}

There was a significant interaction between $+\mathrm{N}$ and $+\mathrm{P}$ on growth of $\mathrm{Hyp}$ nea musciformis (Fig. 4a). In experimental units where $\mathrm{N}$ or $\mathrm{P}$ were added alone, algal growth more than doubled over no-addition controls. When both $\mathrm{N}$ and $\mathrm{P}$ were added, growth was the highest.

There was also a significant interaction between $+\mathrm{N}$ and $+\mathrm{P}$ on concentration of $\mathrm{N}$ in Hypnea musciformis (Fig. 4b). Tissue $\mathrm{N}$ concentration decreased in all treatments except where $\mathrm{N}$ was added alone. There was also a significant interaction on total $\mathrm{N}$ mass in algal tissue. While $\mathrm{N}$ mass accumulated in the tissue of algae in the $+\mathrm{N}$ treatment, it accumulated to a lesser degree in the $+\mathrm{N}+\mathrm{P}$ treatment, resulting in the significant interaction.

$\mathrm{NO}_{3}$ was below the detection limit in 15 of 20 experimental units, so enriched and unenriched treatments could not be analyzed separately. When comparing all the remaining pooled initial versus all pooled final concentrations of $\mathrm{NO}_{3}$, Hypnea musciformis reduced the concentration from a grand mean of $11.05 \mu \mathrm{M}(\mathrm{SE}=2.09)$ to $4.14 \mu \mathrm{M}(\mathrm{SE}=0.27)$ after $3 \mathrm{~d}$ ( $t$-test: $\mathrm{p}=0.0467$; Table 1$)$. TP was below the detection limit in 14 of 20 experimental units. Similarly, TP was reduced by almost half in the remaining experimental units (grand mean [SE] $=2.88 \mu \mathrm{M}$ [0.32] vs grand mean $1.56 \mu \mathrm{M}[0.0] ; t$-test: $\mathrm{p}=0.0076)$. Concentrations of DON were also reduced from initial values (grand mean $[\mathrm{SE}]=38.69 \mu \mathrm{M}[7.17]$ vs grand mean $17.34 \mu \mathrm{M}$ [1.05]; $t$-test: $\mathrm{p}=0.0007) . \mathrm{NH}_{4}$ was above the detection limit in only 7 of 20 experimental units. 


\section{Hypnea musciformis}
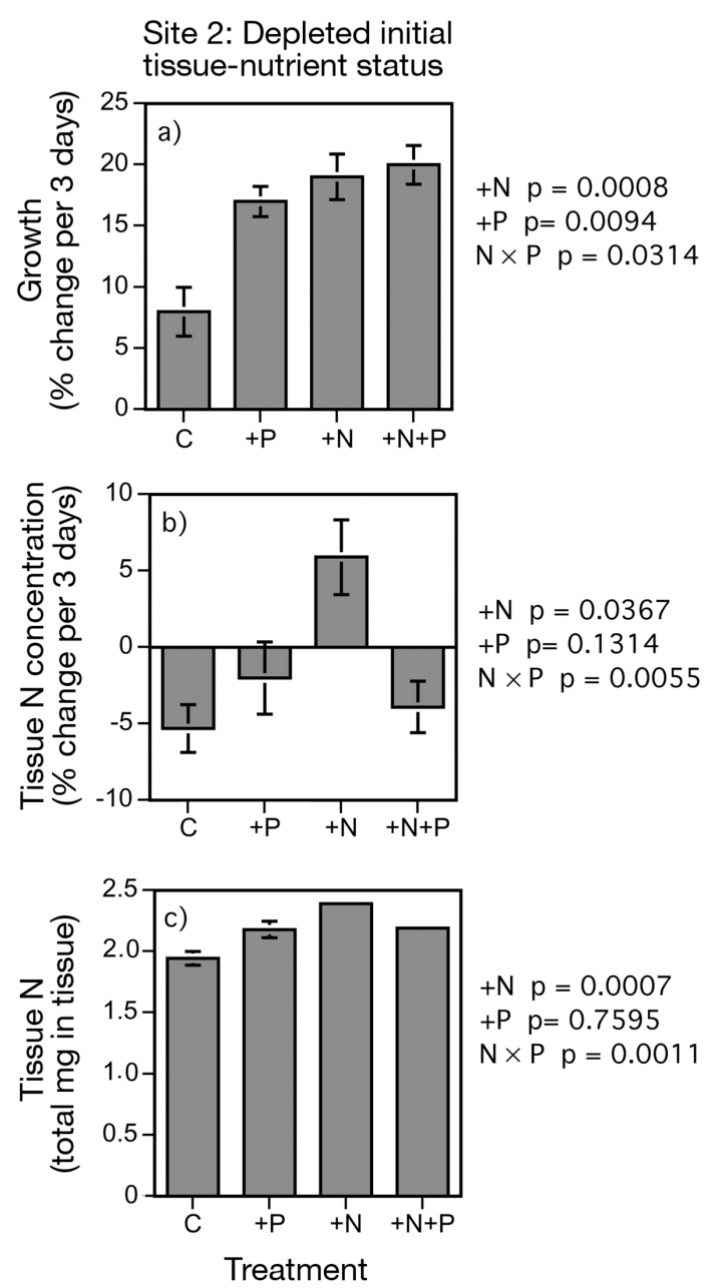

Fig. 4. Hypnea musciformis. Responses to experimental nutrient addition. Bars $=$ SE. Statistical results of a 2 -factor ANOVA are given to the right of each panel. p-values are included for each factor $(+N,+P)$ as well as for any significant interactions

\section{DISCUSSION}

Our results suggest the tissue-nutrient status of tropical marine macroalgae strongly influenced their growth in response to $+\mathrm{N}$ and $+\mathrm{P}$. Both $\mathrm{N}$ and $\mathrm{P}$ enhanced growth of coarsely branched and sheet-like algae with low internal stores of nutrients. Limitation of growth or photosynthesis by both $\mathrm{N}$ and $\mathrm{P}$ has been documented in other studies. Littler et al. (1991) measured the photosynthetic response of 14 species of algae from differing habitats in response to nutrient additions. Five of these species from a low-nutrient environment, including calcified green and corticated red algae, responded by increasing photosynthesis when either N or P was added. Sargassum baccularia from the GBR was limited by both $\mathrm{N}$ and $\mathrm{P}$ in summer (Schaffelke \& Klumpp 1998a), whereas Gracilaria tikvahiae in the Florida Keys increased growth and photosynthesis when either $\mathrm{N}$ or $\mathrm{P}$ was added in the winter (Lapointe 1987, 1989). Other fleshy algae from a eutrophic site in the Florida Keys were stimulated by both nutrients (Delgado \& Lapointe 1994). However, many studies have found limitation by either $\mathrm{N}$ or $\mathrm{P}$, but not both. Lapointe (1989) tested 3 species of coarsely branched and fleshy macroalgae that were only stimulated by $+P$. Similarly, Larned (1998) found stimulation of growth by either $\mathrm{N}$ (8 of 9 species) or $\mathrm{P}$ (1 of 9 species) for a wide range of functional forms of algae from Kaneohe Bay, Hawaii, while none of the species was stimulated by both nutrients. The 3 species that were stimulated by both nutrients in our experiments (Acanthophora spicifera, Dictyota cervicornis, and Hypnea musciformis) are all opportunistic algae with relatively high surface area-to-volume ratios (Littler \& Littler 1980, Steneck \& Watling 1982, Steneck \& Dethier 1994), and the functional form model predicts these algae should have the ability to respond quickly to nutrients by increasing growth.

In contrast, we found fewer effects of $+\mathrm{N}$ or $+\mathrm{P}$ on growth of algae with initially high internal stores relative to those from low-nutrient sites (Fong et al. 2001). Although the magnitude of the response was lower, Acanthophora spicifera from the enriched site was stimulated by $+\mathrm{P}$ alone as well as the addition of both nutrients. Littler et al. (1991) found that algae from a high-nutrient environment did not increase photosynthesis rates in response to nutrient additions. Although not tested directly, some investigators hypothesized that nutrient limitation may shift from $\mathrm{P}$ to $\mathrm{N}$ along a gradient from low to high nutrient supply (Delgado \& Lapointe 1994, Downing et al. 1999). Our results did not support this hypothesis, as, in general, nutrients were not as limiting to growth of algae with relatively high internal nutrient supplies.

Both theoretical models and empirical data (Hanisak 1983) predict higher growth in algae with higher internal stores of nutrients. Our results were the opposite, with consistently slower growth in algae with initially higher internal stores. While there is ample evidence that pulses of elevated $\mathrm{N}$ enhance nutrient uptake dramatically for nutrient-depleted algae compared to nutrient-enriched algae (e.g. Fujita 1985, Fujita et al. 1988, McGlathery et al. 1996), we know of no studies that suggest this uptake is translated to faster growth. It is possible that, when internal stores are high, growth, like assimilation, is steady-state, whereas surge uptake results in 'surge growth' over a short period of time.

In our $3 \mathrm{~d}$ experiments, the calcified alga Halimeda incrassata never showed a growth response, regardless of tissue-nutrient status. $H$. incrassata has a very differ- 
ent growth form and thallus morphology than the other algae tested. This alga has a rhizoid that usually allows it to access sediment nutrients. It is possible that the lack of response in our experiment was due to removal of this rhizoid for experimental purposes; in an effort to make Halimeda incrassata more comparable to the other algae in the experiment, we may have reduced its ability to take up nutrients and grow. However, the experimental algae did take up much of the available nutrients over the course of the experiment, resulting in depleted water and significant tissue-nutrient storage; this suggests that the ability to take up nutrients, at least, was not entirely inhibited. $H$. incrassata also has a relatively low surface area-to-volume ratio compared to the other algae; therefore, nutrient uptake may have been slower simply due to the morphology, translating to slower and more variable growth over $3 \mathrm{~d}$. Others found that nutrient enrichment enhanced oxygen production of fleshy algae more than calcareous green algae (Delgado \& Lapointe 1994), and these differences in productivity may result in variations in growth. Alternatively, $\mathrm{N}$ or $\mathrm{P}$ may not limit growth of calcareous green algae. To our knowledge, Halimeda has never been associated with nuisance blooms in response to eutrophication. In addition, $H$. incrassata from a lagoon in Guam did not respond to nutrients in a $9 \mathrm{~d}$ experiment (Kuffner \& Paul 2001); the authors attribute this lack of response to the nutrientreplete condition of the algae. It is possible that $H$. incrassata is limited by other metabolic processes, such as calcification, rather than by nutrients.

Tissue $\mathrm{N}$-content of filamentous and sheet-like algae that were initially nutrient-depleted was strongly affected by $+\mathrm{N}$. Dictyota cervicornis, Acanthophora spicifera, and Hypnea musciformis responded to $+\mathrm{N}$ by increasing $\mathrm{N}$-stores. These algae were able to respond to increased nutrients very rapidly by taking up nutrients, sequestering them in their tissues to support future growth, and growing. Other algae with similar morphological forms have also been found to store nutrients supplied in pulses. Rosenburg \& Ramus (1982) found that Ulva sp. and Gracilaria folifera had peaks in tissue $\mathrm{N}$ following nutrient peaks in ambient seawater. Duke et al. (1989) found that Ulva curvata responded to nutrient pulses by storing nutrients for growth when supplies were limiting. In addition, they measured higher uptake rates for $U$. curvata when $\mathrm{N}$ was supplied in pulses rather than continuously. Ramus \& Venable (1987) also found that some forms of fleshy algae were capable of rapid nutrient uptake and growth in response to pulses of $\mathrm{NH}_{4}$. This ability may be very adaptive in areas of low nutrient concentration, where nutrients may be supplied in occasional pulses. Rapid uptake and storage of nutrients can extend the effect of nutrient pulses past the duration of the pulse.
In contrast, when tissues were initially enriched, tissue $\mathrm{N}$-content of 2 of these same algal species (Dictyota cervicornis, Acanthophora spicifera) was not affected by external nutrient supply. In this case, changes in tissue $\mathrm{N}$-content for enriched algae were primarily driven by dilution of internal $\mathrm{N}$-content to support growth. However, for enriched $D$. cervicornis and, to a lesser extent, A. spicifera, the reduction in tissue $\mathrm{N}$ was greater than can be attributed solely to growth i there was a net loss of $\mathrm{N}$ mass. It is possible these enriched algae were leaking nutrients to the water. Nonsignificant trends of increased $\mathrm{NH}_{4}$ in the water support this hypothesis.

Halimeda incrassata had the opposite initial tissuenutrient content than we would predict based on water and sediment sampling and the initial tissue $\mathrm{N}$ - and $\mathrm{P}$ content of the other species collected in close proximity. In addition, $H$. incrassata from Site 2 increased internal supplies of nutrients in a similar pattern to those of the 2 other species from this site, while $H$. incrassata from Site 1 demonstrated little change in tissue concentrations, regardless of the reversal in initial conditions. Thus, $H$. incrassata responded to nutrient treatments as if it had the same pattern in initial tissue conditions between sites like Acanthophora spicifera and Hypnea musciformis. These results support our earlier suggestion that our measures of tissuenutrient content may be confounded by differences in amount of calcium carbonate deposition within thalli between sites. Thus, while we may compare differences in tissue nutrients among treatments for $H$. incrassata within a site, comparisons between sites may not be appropriate. Future studies should use decalcified tissue or ash-free dry wt as a measure of biomass for calcified algae.

Over the $3 \mathrm{~d}$ experiment, additions of both $\mathrm{NO}_{3}$ and $\mathrm{PO}_{4}$ were reduced to or below ambient levels by all species of algae, regardless of their tissue-nutrient status. While it is very probable that there were large differences in uptake between enriched and depleted algae, especially at the beginning of the experiment (Fujita 1985, McGlathery et al. 1996), our experiment was not designed to measure uptake as the timescale was much too long. After $3 \mathrm{~d}$, water nutrient concentrations were not measurably different in experimental units containing algae with differing initial tissuenutrient status. Ambient concentrations of DON were also reduced over the $3 \mathrm{~d}$. Many macroalgae have been found to utilize DON directly (for a review, see Hanisak 1983). In addition, DON may have been transformed to inorganic $\mathrm{N}$ over time, and used by the algae in that form. The use of a secondary source of $\mathrm{N}$ in the form of DON, especially for nutrient-depleted algae, may be an important mechanism for bloom-forming algae to secure nutrients in tropical systems. Our data 
suggest organic $\mathrm{N}$ may be more much abundant than inorganic forms in shallow nearshore habitats.

There is considerable evidence linking the tissuenutrient status of algae to the nutrient history of a site (Horrocks et al. 1995, Lyngby et al. 1999, Fong et al. 2001). Because water-column nutrients in tropical systems are typically low, and are often supplied in pulses (Genin et al. 1995, Diaz \& Ward 1997), there is considerable spatial and temporal variation in tissue-nutrient status of algae in the field (Fong et al. 2001). Although many nutrient-limitation experiments measure tissue $\mathrm{N}$ and $\mathrm{P}$ as a response to nutrient enrichment (Lapointe 1987, Larned \& Stimson 1997, Larned 1998, Schaffelke \& Klumpp 1998a), or characterize the trophic status of the study site (Delgado \& Lapointe 1994), few explicitly take the initial tissue-nutrient status of the algae into account when designing experiments (but see Littler et al. 1991). Our experimental results demonstrated strong interactions between $+\mathrm{N}$ and $+\mathrm{P}$ and nutrient history on growth and accumulation of nutrients in algal tissue. These complex interactions may contribute to the often mixed results that occur during investigation of the relative importance of $\mathrm{N}$ - and $\mathrm{P}$ limitation of marine algae, and they demonstrate the value of explicitly incorporating tissue-nutrient status into experimental designs.

Acknowledgements. This work was funded by the Academic Senate of the University of California at Los Angeles and by US EPA (project \#021925 to P.F.). Our deepest thanks to E. Weil at the University of Puerto Rico for hosting us in his laboratory and for his advice and help with logistics. We would also like to thank M. Carlo, University of Puerto Rico's Dive Safety Officer, and G. Lopez for all their help with site location and local knowledge. Our thanks also to the 4 anonymous reviewers for their thoughtful and thorough comments; we believe they have helped to improve the quality of this manuscript with their contributions.

\section{LITERATURE CITED}

Carlson RM (1978) Automated separation and conductimetric determination of ammonia and dissolved carbon dioxide. Anal Chem 50:1528-1531

Delgado O, Lapointe BE (1994) Nutrient-limited productivity of calcareous versus fleshy macroalgae in a eutrophic, carbonate-rich tropical marine environment. Coral Reefs 13:151-159

Delgado O, Rodriguez-Prieto C, Gacia E, Ballesteros E (1996) Lack of severe nutrient limitation in Caulerpa taxifolia (Vahl) C. Agardh, an introduced seaweed spreading over the oligotrophic northwestern Mediterranean. Bot Mar 39:61-67

Diaz MC, Ward BB (1997) Sponge-mediated nitrification in tropical benthic communities. Mar Ecol Prog Ser 156: 97-107

Downing JA, McClain M, Twilley RW, Melack JM and 9 others (1999) The impact of accelerating land-use change on the Ncycle of tropical aquatic ecosystems: current conditions and projected changes. Biogeochemistry 46:109-148
Duarte CM (1992) Nutrient concentration of aquatic plants: patterns across species. Limnol Oceanogr 37:882-889

Duke CS, Litaker RW, Ramus J (1989) Effect of temperature, nitrogen supply, and tissue nitrogen on ammonium uptake rates of the Chlorophyte seaweeds Ulva curvata and Codium decorticatum. J Phycol 25:113-120

Fong P, Zedler JB, Donohoe RM (1993) Nitrogen versus phosphorus limitation of algal biomass in shallow coastal lagoons. Limnol Oceanogr 38:906-923

Fong P, Donohoe RM, Zedler JB (1994) Nutrient concentration in tissue of the macroalga Enteromorpha spp. as an indicator of nutrient history: an experimental evaluation using field microcosms. Mar Ecol Prog Ser 106:273-281

Fong P, Kamer K, Boyer KE, Boyle KA (2001) Nutrient content of macroalgae with differing morphologies may indicate sources of nutrients to tropical marine systems. Mar Ecol Prog Ser 220:137-152

Franson MAH (1985) Method 424-F. In: Eaton AD, Clesceri LS, Greenberg AE (eds) Standard methods for the examination of water and wastewater, 16th edn. APHA, AAWA, and WPCF. American Public Health Association, Washington, DC, p 448-450

Fujita RM (1985) The role of nitrogen status in regulating transient ammonium uptake and nitrogen storage by macroalgae. J Exp Mar Biol Ecol 92:283-301

Fujita RM, Wheeler PA, Edwards RL (1988) Metabolic regulation of ammonium uptake by Ulva rigida (Chlorophyta): a compartmental analysis of the rate-limiting step for uptake. J Phycol 24:560-566

Fujita RM, Wheeler PA, Edwards RL (1989) Assessment of macroalgal nitrogen limitation in a seasonal upwelling region. Mar Ecol Prog Ser 53:293-303

Gallegos CL, Jordan TE (1997) Seasonal progression of factors limiting phytoplankton pigment biomass in the Rhode River estuary, Maryland (USA). II. Modeling N versus P limitation. Mar Ecol Prog Ser 161:199-212

Gallegos CL, Jordan TE, Correll DL (1997) Interannual variability in spring bloom timing and magnitude in the Rhode River, Maryland, USA: observations and modeling. Mar Ecol Prog Ser 154:27-40

Genin A, Lazar B, Brenner S (1995) Vertical mixing and coral death in the Red Sea following the eruption of Mount Pinatubo. Nature 377:507-510

Hanisak MD (1983) The nitrogen relationships of marine macroalgae. In: Carpenter EJ, Capone DG (eds) Nitrogen in the marine environment. Academic Press, New York, p 699-730

Hanisak MD, Littler MM, Littler DS (1988) Significance of macroalgal polymorphism: intraspecific tests of the functional form model. Mar Biol 99:157-165

Hatcher BG (1988) Coral reef primary productivity: a beggar's banquet. TREE 3:106-111

Horrocks JL, Stewart GR, Dennison WC (1995) Tissue nutrient content of Gracilaria spp. (Rhodophyta) and water quality along an estuarine gradient. Mar Freshw Res 46:975-983

Johnson CM, Ulrich A (1959) Analytical methods for use in plant analysis. Bulletin 766. Agricultural Experiment Station, University of California, Berkeley

Koop K, Booth D, Broadbent A, Brodie J and 16 others (2001) ENCORE: the effect of nutrient enrichment on coral reefs. Synthesis of results and conclusions. Mar Pollut Bull 41: 91-120

Kuffner IB, Paul VJ (2001) Effects of nitrate, phosphate and iron on the growth of macroalgae and benthic cyanobacteria from Cocos lagoon, Guam. Mar Ecol Prog Ser 222: 63-72

Lapointe BE (1987) Phosphorus- and nitrogen-limited photo- 
synthesis and growth of Gracilaria tikvahiae (Rhodophyceae) in the Florida Keys: an experimental field study. Mar Biol 93:561-568

Lapointe BE (1989) Macroalgal production and nutrient relations in oligotrophic areas of Florida Bay. Bull Mar Sci 44:312-323

Lapointe BE (1997) Nutrient thresholds for bottom-up control of macroalgal blooms on coral reefs in Jamaica and southeast Florida. Limnol Oceanogr 42:1119-1131

Lapointe BE, Duke CS (1984) Biochemical strategies for growth of Gracilaria tikvahiae (Rhodophyta) in relation to light intensity and nitrogen availability. J Phycol 20:488-495

Lapointe BE, Littler MM, Littler DS (1987) A comparison of nutrient-limited productivity in macroalgae from Caribbean barrier reef and from mangrove ecosystem. Aquat Bot 28: 243-255

Lapointe BE, Littler MM, Littler DS (1992) Nutrient availability to marine macroalgae in siliciclastic versus carbonaterich coastal waters. Estuaries 15:75-82

Larkum AWD, Koop K (1997) ENCORE, algal productivity and possible paradigm shifts. Proc 8th Int Coral Reef Symp 2:881-884

Larned ST (1998) Nitrogen- versus phosphorus-limited growth and sources of nutrients for coral reef macroalgae. Mar Biol 132:409-421

Larned ST, Stimson J (1997) Nitrogen-limited growth in the coral reef chlorophyte Dictyosphaeria cavernosa, and the effect of exposure to sediment-derived nitrogen on growth. Mar Ecol Prog Ser 145:95-108

Lirman D, Biber P (2000) Seasonal dynamics of macroalgal communities of the Northern Florida Reef Tract. Bot Mar 43:305-314

Littler MM, Littler DS (1980) The evolution of thallus form and survival strategies in benthic marine macroalgae: field and laboratory tests of a functional form model. Am Nat 116:25-44

Littler MM, Littler DS, Lapointe BE (1988) A comparison of nutrient and light-limited photosynthesis in psammophytic versus epilithic forms of Halimeda caulerpales Halimedaceae from the Bahamas. Coral Reefs 6:219-226

Littler DS, Littler MM, Titlyanov EA (1991) Comparisons of Nand P-limited productivity between high granatic islands vs. low carbonate atolls in the Seychelles Archipelago: a test of the relative-dominance paradigm. Coral Reefs 10: 199-209

Lyngby JE, Mortensen S, Ahrensberg N (1999) Bioassessment techniques for monitoring of eutrophication and nutrient limitation in coastal ecosystems. Mar Pollut Bull 39: 212-223

McCook LJ (1996) Effects of herbivores and water quality on Sargassum distribution on the central Great Barrier Reef: cross-shelf transplants. Mar Ecol Prog Ser 139:179-192

McCook LJ (1999) Macroalgae, nutrients and phase shifts on coral reefs: scientific issues and management consequences for the Great Barrier Reef. Coral Reefs 18:357-367

McGlathery KJ, Marino R, Howarth RW (1994) Variable rates of phosphorus uptake by shallow marine carbonate sediments: mechanisms and ecological significance. Biogeochemistry 25:127-146

McGlathery KJ, Pedersen MF, Borum J (1996) Changes in intracellular nitrogen pools and feedback controls on nitrogen uptake in Chaetomorpha linum (Chlorophyta). J Phycol 32:393-401

Nixon SW (1995) Coastal marine eutrophication: a definition, social causes, and future concerns. Ophelia 41:199-219

Nixon SW, Granger SL, Nowicki BL (1995) An assessment of the annual mass balance of carbon, nitrogen, and

Editorial responsibility: Charles Birkeland (Contributing

Editor), Honolulu, Hawaii, USA phosphorus in Narragansett Bay. Biogeochemistry 31: 15-61

Ramus J, Venable M (1987) Temporal ammonium patchiness and growth rate in Codium and Ulva (Ulvophyceae). J Phycol 23:518-523

Redfield AC, Ketchum BA, Richards FA (1963) The influence of organisms on the chemical composition of sea-water. In: Hill MN (ed) The sea, Vol 2. John Wiley, New York

Rivers JS, Peckol P (1995) Interaction effects of nitrogen and dissolved inorganic carbon on photosynthesis, growth, and ammonium uptake of the macroalgae Cladophora vagabunda and Gracilaria tikvahiae. Mar Biol 121:747-753

Rosenburg G, Ramus J (1982) Ecological growth strategies in the seaweeds Gracilaria foliifera (Rhodophyceae) and Ulva sp. (Chlorophyceae): soluble nitrogen and reserve carbohydrates. Mar Biol 66:251-259

Schaffelke B, Klumpp DW (1997) Growth of germlings of the macroalga Sargassum baccularia (Phaeophyta) is stimulated by enhanced nutrients. Proc 8th Int Coral Reef Symp 2:1839-1842

Schaffelke B, Klumpp DW (1998a) Nutrient-limited growth of the coral reef macroalga Sargassum baccularia and experimental growth enhancement by nutrient addition in continuous flow culture. Mar Ecol Prog Ser 164:199-211

Schaffelke B, Klumpp DW (1998b) Short-term nutrient pulses enhance growth and photosynthesis of the coral reef macroalga Sargassum baccularia. Mar Ecol Prog Ser 170: 95-105

Sfriso A (1995) Temporal and spatial responses of growth of Ulva rigida C. Ag. to environmental and tissue concentrations of nutrients in the Lagoon of Venice. Bot Mar 38: $557-573$

Sfriso A, Marcomini A (1997) Macrophyte production in a shallow coastal lagoon. Part I. Coupling with chemicophysical parameters and nutrient concentrations in waters. Mar Environ Res 44:351-375

Steneck RS, Dethier MN (1994) A functional group approach to the structure of algal-dominated communities. Oikos 69:476-498

Steneck RS, Watling L (1982) Feeding capabilities and limitation of herbivorous Molliscs: a functional group approach. Mar Biol 68:299-319

Sweeney RA (1989) Generic combustion method for determination of crude protein in feeds: a collaborative study. J Assoc Off Anal Chem 72:770-774

Szmant AM (1997) Nutrient effects on coral reefs: a hypothsis on the importance of topographic and trophic complexity to reef nutrient dynamics. Proc 8th Int Coral Reef Symp 2: $1527-1532$

Taylor DI, Nixon SW, Granger SL, Buckley BA, McMahon JP, Lin HJ (1995) Responses of coastal lagoon plant communities to different forms of nutrient enrichment: a mesocosm experiment. Aquat Bot 52:19-34

Thybo-Christesen M, Rasmussen MB, Blackburn TH (1993) Nutrient fluxes and growth of Cladophora sericea in a shallow Danish bay. Mar Ecol Prog Ser 100:273-281

Wheeler PA, Björnsäter BR (1992) Seasonal fluctuations in tissue nitrogen, phosphorus, and N:P for five macroalgal species common to the Pacific northwest coast. J Phycol 28:1-6

Wheeler PA, North WJ (1980) Effect of nitrogen supply on nitrogen content and growth rate of juvenile Macrocyctis pyrifera (Phaeophyta) sporophytes. J Phycol 16:577-582

Williams SL, Carpenter RC (1998) Effects of unidirectional and oscillatory water flow on nitrogen fixation (acetylene reduction) in coral reel algal turfs, Kaneohe Bay, Hawaii. J Exp Mar Biol Ecol 226:293-316 